Politica, Vol. 7, No. 2, Juli-Desember 2020

\title{
PEMBATASAN KEKUASAAN BERDASARKAN PAHAM KONSTITUSIONALISME DI NEGARA DEMOKRASI
}

\author{
Oleh: Ro'is Alfauzi dan Orien Effendi \\ Mahasiswa Program Magister Ilmu Syari'ah Fakultas Syari'ah dan \\ Hukum Universitas Islam Negeri Sunan Kalijaga Yogyakarta \\ Email: alfauzirois21@gmail.com ${ }^{1}$, orieneffendi3@gmail.com²
}

\begin{abstract}
Abstrak
Pembatasan Kekuasaan Berdasarkan Paham Konstitusionalisme di Negara Demokrasi adalah perlunya pembatasan terhadap bentuk kekuasaan yang ada, batasan itu sudah di amanatkan dalam konstitusi negara tidak terkecuali menurut paham konstitusionalisme. Tujuan penelitian ini untuk mengetahui tentang bagaimana pembatasan dalam kekuasaan yang dimiliki oleh organ atau lembaga dalam suatu negara hukum dengan menjadikan konsep atau paham konstitusionalisme sebagai tolak ukur. Penelitian ini berusaha mengungkap tiga cabang lembaga pemerintahan yang memiliki kekuasaan di Indonesia, yakni kekuasaan eksekutif, legislatif dan yudikatif. Dengan menggunakan metode pendekatan yuridis normatif maka pembatasan kekuasaan lembaga pemerintah dalam suatu negara tersebut dapat kita lihat melalui dokumen, teori-teori hukum, dan peraturan undang-undang yang tertuang dalam konstitusi negara. Dengan cara penelitian tersebut nantinya kita bisa melihat bagaimana kekuasaan yang dimiliki oleh pemegang kekuasaan tersebut dalam mengaplikasikan kebijakan yang dikeluarkannya sesuai dengan nilai konstitusi atau tidak.
\end{abstract}

Kata Kunci: Konstitusionalisme, Demokrasi, Kekuasaan, Negara.

\section{A. Pendahuluan}

Sejarah dunia selalu memperhatikan dan memperlihatkan adanya suatu kelompok yang menjadi cikal bakal lahirnya masyarakat. Sejak awal dalam kesadarannya manusia senantiasa membutuhkan manusia yang lain. Manusia sadar membentuk dan berada dalam komunitas sosialnya agar dapat meresapi keberadaan kehidupan, setelah sejarah panjang kelompok manusia yang semakin membesar dan membuat aturan yang sejak awal telah disusun secara bersama oleh anggota 
Politica, Vol. 7, No. 2, Juli-Desember 2020

komunitas mengalami gerak evolusi dengan tata nilai dan aturan yang kian kompleks.

Saat itu masyarakat mengalami sebuah fase persebarannya dengan jejaring sistem pemerintahan yang kian rumit dan menjadi latar belakang terbentuknya negara. Dalam sebuah negara, kelompokkelompok sosial yang telah ada secara keseluruhan adalah warga negara yang merefleksikan pekerjaan dan pandangan-pandangan politik, kepercayaan-kepercayaan terhadap agama dan gaya hidup didalamnya. ${ }^{1}$ Di mana ada satu kelompok yang meliputi itu semua bernama negara. Setiap negara selalu mempunyai konsep dalam sistem kenegaraannya baik di negara kesatuan mapun negara federal, dalam hal ini mengingat didalam negara terdapat masyarakat yang mempunyai hak kedaulatan dalam menyampaikan aspirasi maka dibutuhkan konsep negara yang menjunjung tinggi opini tersebut yaitu dengan ditetapkannya suatu konsep yang dinamakan demokrasi.

Demokrasi mempunyai arti penting bagi lapisan masyarakat yang menggunakannya, sebab demokrasi adalah hak masyarakat untuk menentukan sendiri jalan hidup organisasi suatu negara. Konsep demokrasi lahir dari pemikiran mengenai hubungan negara dan hukum, di yunani kuno telah diipraktekkan dalam kehidupan bernegara dalam abad ke 5 SM hingga abad ke 6 M ketika itu pelaksanaan demokrasi dipraktekan yang bersifat langsung (direct democracy), artinya hak rakyat dalam membuat keputusan-keputusan politik dijalankan secara langsung oleh seluruh warga negara yang bertindak berdasarkan prosedur mayoritas.

Sejak dimunculkannya asas demokrasi telah menimbulkan masalah tentang siapakah yang berperan dalam menentukan jalannya negara sebagai organisasi tertinggi: negara atau masyarakat, atau sebaliknya masyarakat atau negara. ${ }^{2}$ Didalam negara modern terdapat dua karakteristik utama yang digunakan yaitu dianutnya prinsip demokrasi

\footnotetext{
${ }^{1}$ Mansyur Semma, Negara dan Korupsi: Pemikiran Mochtar Lubis Atas Negara, Manusia Indonesia, dan Perilaku Politik, (Jakarta: Yayasan Obor Indonesia, 2008), 2.

${ }^{2}$ Moh. Mahfud M. Demokrasi dan Konstitusi di Indonesia: Studi Tentang Interaksi Politik dan Kehidupan Ketatanegaraan, (Jakarta: PT. Rineka Cipta, 2000), 20.
} 
Politica, Vol. 7, No. 2, Juli-Desember 2020

dan adanya sebuah konstitusi yang menjadi hukum dasar bagi kehidupan berbangsa dan bernegara. Kedua karakteristik tersebut bukannya tidak saling terhubung akan tetapi justru tidak terspisahkan. Konstitusi dapat diartikan sebagai salah satu wujud sekaligus piranti hukum demokrasi.

Demokrasi modern dibangun atas prinsip dari sebuah kedaulatan rakyat, yang dapat diartikan kekuasaan tertinggi dalam suatu negara ada ditangan rakyat. Kekuasaan tersebut ditransformasikan dalam organisasi negara melalui teori perjanjian sosial untuk dasar berdiri dan penyelenggaraan negara dan juga disepakati prinsip-prinsip dasar penyelenggaraan negara, hak warga negara yang harus dilindungi, serta organisasi penyelenggaraan negara. Didalam demokrasi modern keberadaan negara diasumsikan atas bentukan rakyat dan untuk memenuhi kebutuhan atau kepentingan seluruh rakyat. Kesepakatan bersama seluruh rakyat yaitu diwujudkan dalam bentuk dokumen dasar berdirinya negara demokrasi yaitu konstitusi. Mengingat bahwa kesepakatan yang dibuat adalah oleh seluruh rakyat yang merupakan pemegang kekuasaan tertingi, maka konstitusi pun menjadi hukum tertinggi dalam kehidupan berbangsa dan bernegara (the supreme law of the land). ${ }^{3}$

Semua konsep dari konstitusi khususnya dalam negara modern yang plural, selalu dimuati oleh nilai-nilai luhur yang bersifat universal parrenial dan hal-hal dasar yang disepakati bersama oleh segenap komponen warga yang bersangkutan meskipun masing-masing mempunyai latarbelakang agama, keyakinan ataupun budaya berbedabeda, adapun dalam konstitusi terdapat sebuah paham konstitusionalisme. Paham konstitusionalisme telah meletakakkan sebuah dasar pembatasan kekuasaan yang telah dirumuskan dalam konstitusi negara demokrasi. Nilai-nilai fundamental yang telah mendasari pembatasan kekuasaan adalah untuk mencegah terjadinya dominasi kekuasaaan oleh para penyelenggara negara sekaligus dengan bertujuan melindungi harkat dan martabat manusia. Pembatasan

3 Muchamad Ali Syafa'at, Konstitusi dan Demokrasi, (Malang: Universitas Brawijaya, 2014), 1. 
Politica, Vol. 7, No. 2, Juli-Desember 2020

kekuasaan tersebut secara praktis berujung dan bertujuan pada kesejahteraan masyarakat.

Menurut Plato penyelenggaraan negara yang baik ialah didasarkan pada pengaturan hukum yang baik, beberapa pemikir besar dalam ketata negaraan semisal John Locke, Montesquieu dan lain sebagainya memiliki keinginan senada bahwa kekuasaan negara harus dibatasi agar tidak berjalan menurut logikannya sendiri. Alternatif pembatasan kekuasaan yang mereka tawarkan ialah dengan pemisahan kekuasaankekuasaan yang ada didalam negara agar tidak bertumpuk dalam satu tangan, menurut Montesquieu kemerdekaan individu hanya dapat terjamin kalau kekuasaan raja tidak terpusat di satu tangan tetapi disentraslisasi. ${ }^{4}$

Idealnya kontruksi sebuah kekuasaan yang dibangun baik dalam kekuasaan legislatif, eksekutif mapun yudikatif dalam sebuah negara dituntut memahami ide dasar dari paham konstitusionalisme tersebut, namun dalam praktik, hal tersebut akan sangat bergantung pada sebuah keinginan dan kesadaran dari kekuatan politik. Para penyelenggara negara juga diharuskan memahami gagasan yang terdapat dalam pasalpasal konstitusi secara utuh dan tidak secara parsial agar dengan adanya pemahaman tersebut, cara pandang, cara penyelesaian masalah dan cara bertindak seluruh elemen bangsa pada saat sekarang dan kedepan harus merujuk dan berdasar pedoman pada konstitusi, karena paham konstitusionalisme akan tampak dalam sebuah praktik kenegaraan. ${ }^{5}$

\section{B. Memahami Konstitusionalisme}

Istilah konstitusionalisme sebenarnya merupakan sesuatu yang telah lama diperdebatkan dan menjadi pergulatan pemikiran para pendiri bangsa (founding fathers) pada waktu itu dalam penyusunan dasar-dasar Negara Indonesia merdeka. Setidaknya terdapat tiga mainstream ide yang telah mengemuka ketika itu. Pertama, arus

4 Utrecht, Pengantar Hukum Administrasi Negara Indonesia. Cet ke 4, (Surabaya: Pustaka Tinta Mas. 1986), 19.

5 Hamdan Zoelfa, Konstitualisme Indonesia Untuk Pembatasan Kekuasaan diakses dari https://mkri.id/index.php?page=web.Berita\&id=7775, pada 9 Oktober 2020. 
Politica, Vol. 7, No. 2, Juli-Desember 2020

pemikiran yang menghendaki diberlakukannya Islam sebagai dasar negara yang didukung Abikusno Tjokrosujoso, Agus Salim dan Wachid Hasyim. Kedua, arus pemikiran yang menghedaki negara kebangsaan dengan mengacu kepada Negara integralistik yang diprakarsai Prof. Soepomo dan didukung oleh Ir. Soekarno. Ketiga, arus pemikiran yang menghendaki negara konstitusional yang diprakarsai oleh Mohammad Hatta dan Mohammad Yamin. ${ }^{6}$

Konstitusionalisme adalah gagasan bahwasannya pemerintahan itu merupakan suatu kumpulan kegiatan yang diselenggarakan oleh dan atas nama rakyat, tetapi yang dikenakan beberpa pembatasan yang diharapkan akan menjamin bahwa kekuasaan yang diperlukan untuk pemerintahan itu tidak disalahgunakan oleh mereka yang mendapat tugas untuk memerintah dengan cara yang dianggap efektif adalah dengan jalan membagi kekuasaan. Menurut Adnan Buyung Nasution bahwa konstitusionalisme itu bukan sekedar pemerintahan negara yang berkonstitusi melainkan pemerintahan yang kekuasaannya terbatas (dibatasi oleh hukum) dan bertanggung jawab kepada rakyat. Dalam hal ini mengingat bahwa sifat kekuasaan tersebut cenderung untuk diselewengkan ataupun disalahgunakan maka dengan cara pembatasan dianggap paling efektif yaitu dengan jalan membagi kekuasaan.

Signifikasi pembatasan kekuasaan negara bukan hanya berlaku didalam negara yang menganut paham negara hukum akan tetapi juga di negara yang menganut paham kedaulatan rakyat (demokrasi). Dalam konsep negara demokrasi konstitusi memuat wewenang, tanggung jawab, hak dan tugas yang memerintah, hak-hak yang diperintah, dan hubungan antara yang memerintah dan yang diperintah. Secara konseptual, paham konstitusionalisme atau paham pembatasan kekuasaan pemerintah negara pertama kali dikenalkan oleh John Locke dalam Two Treatises of Government. ${ }^{7}$ Menurut teori Locke bahwa perlu ada pembatasan kekuasaan pemerintahan negara melalui konstitusi lahir sebagai reaksi dan kesewenangan penguasan yang telah

6 Adnan Buyung Nasution, Arus Pemikiran Konstitusionalisme seri Tata Negara, (Jakarta: Kata Hasta Pustaka, 2007), 39.

${ }^{7}$ Benny K. Herman, Mempertimbangkan Mahkamah Konstitusi, Cet 1, (Jakarta: Gramedia, 2013), 18. 
Politica, Vol. 7, No. 2, Juli-Desember 2020

mengakibatkan hak-hak dan kebebasan hak asasi warga di injak-injak pada peralihan abad ke 17 dan 18. Untuk mencegah pengalaman pahit tersebut maka diperlukan pembatasan kekuasaan pemerintah dengan konstitusi.

Didalam konstitusi ditentukan kelembagaan-kelembagaan negara serta kewenangannya, baik kewenangan negara secara horizontal maupun secara vertikal yaitu yang berkaitan dengan penggunaan wewenang tersebut kepada rakyat. Jadi sesuai dengan azas negara hukum, pada dasarnya dalam setiap penggunaan wewenang harus mempunyai dasar legalitas, sebuah konstitusi yang kompeherensif seharusnya juga menyediakan mekanisme control (checks and balances) agar setiap penyimpangan dalam penggunaan kewenangan dapat dikembalikan pada posisi normatifnya atau sesuai dengan konstitusi.

Dalam hal pembatasan kekuasaan berdasarkan paham konstitusionalisme maka ada tiga ciri negara hukum klasik yaitu:

1. Adanya undang-undang dasar sebagai peraturan tertulis yang mengatur hubungan antara pemerintah dan warganya.

2. Adanya pembagian kekuasaan yang dapat menjamin kemerdekaan kekuasaan kehakiman.

3. Adanya pemencaran kekuasaan negara atau pemerintah.

Ciri-ciri tersebut sudah jelas menghendaki adanya pembatasan atas kekuasaan pemerintah dalam negara yang biasanya pembatasanpembatasan itu dituangkan dalam konstitusi.

Paham konstitusionalisme berupa norma khusus yang fungsinya membatasi kekuasaan dengan prinsip rasional dan negara yang menganut paham tersebut merupakan negara hukum, adapun dengan ciri cirinya yaitu:

1. Berlakunya legalitas sebagai standar yang harus diindahkan atau ide-ide afirmatif yang harus dipenuhi, yang prinsip utamanya adalah keadilan.

2. Adanya peradilan yang bebas tidak memihak.

3. Adanya jaminan hak asasi manusia dalam konstitusi, termasuk penentuan cara prosedural untuk memperoleh hak-hak yang dijamin. 
Politica, Vol. 7, No. 2, Juli-Desember 2020

4. Ditegakannya asas-asas universal pemerintahan yang baik (good government). Maka dengan adanya prinsip tersebut bahwa prinsip demokrasi baru dapat berkembang sebagaimana mestinya.

Menurut Sri Soemantri, sebagaimana yang dikutip oleh Mukhti Fajar, konstitusionalisme memuat aspek prosedural atau formil maupun substansial atau materil dari konstitusi. Aspek prosedural atau formil berkaitan dengan prosedur pembuatan atau prosedur pembuatan konstitusi, serta apakah konsitusi tersebut bersifat supreme atau superior atau bahkan tidak (misal kaitan dengan perjanjian internasional). ${ }^{8}$

\section{Konstitusi Yang Kokoh di Negara Demokrasi}

Suatu konstitusi adalah berdasar pada suatu kesepakatan umum dari seluruh rakyat atau general aggrement bagi suatu bentuk bangunan suatu negara yang didasarkan atas ideal mayoritas rakyat yaitu mengenai bentuk dan tujuan atau cita-cita bersama, sebuah pemikiran dan mekanisme pembagian kekuasaan yang melandasi pemerintahan dan penyelenggaraan negara, serta mengenal bentuk kelembagaan dan prosedur serta mekanisme pengaturan negara yang dicita-citakan. Didalam konstitusi tidak asing dengan adanya supremasi konstitusi yang tidak lain merupakan tujuan negara, maka ketiga komponen sistem hukum harus dapat berjalan secara serasi, dalam kaitannnya dengan sudah dilakukannya amandemen Undang-Undang Dasar (UUD) 1945, karena konstitusi atau Undang-Undang Dasar merupakan hukum dasar atau pegangan dalam penyelenggaraan sebuah negara.

Pembatasan kekuasaan didalam sebuah negara yang demokratis tentunya juga tidak lepas dari keberadaan sebuah konstitusi yang melandasinya. Lebih jauh Abdul Mukhtie Fadjar mengemukakan dalam bukunya Hukum Konstitusi dan Mahkamah Konstitusi bahwa dasar yang paling tepat dan kokoh bagi sebuah negara demokrasi adalah sebuah negara konstitusional (constitutional state) yang berasandar pada sebuah konstitusi yang kokoh pula, konstitusi yang kokoh hanyalah konstitusi yang paham konstitusinya atau

${ }^{8}$ Nuruddin Hady, Teori Konstitusi dan Negara Demokrasi, Edisi Revisi, (Malang: Setara Press, 2016), 47-48. 
Politica, Vol. 7, No. 2, Juli-Desember 2020

konstitusionalismenya, yaitu yang mengatur secara rinci batas-batas kewenangan dan kekuasaan lembaga eksekutif, legislatif, dan yudikatif secara imbang dan saling mengawasi (checks and balances), serta memberikan jaminan yang cukup luas dalam arti penghormatan (to respect), perlindungan (to protect), dan pemenuhan (to fulfill) hak warga negara dan hak asasi manusia atau HAM". 9

Setiap konstitusi menentukan pembatasan terhadap kekuasaan sebagai salah satu fungsi konstitusionalisme tetapi juga memberikan pengesahan terhadap kekuasaan pemerintahan, disamping itu juga berfungsi sebagai instrument atau agregat untuk mengalihkan kewenangan dari pemegang kekuasaan asal rakyat kepada alat-alat kekuasaan negara. Dan konstitusi memiliki kandungan lebih padat dibandingkan dengan UUD, karena konstitusi mengandung unsur legal dan non legal sedangkan UUD hanya mengandung unsur legal, walaupun makna konstitusi seperti itu cenderung diartikan dalam arti konstitusi konvensional dan luas tetapi begitulah konstitusi pada prinsipnya yaitu sebagai peraturan dasar negara yang mengakomodasi segala realitas, nilai dan segala aspek kepentingan dalam negara yang menentukan arah dan tujuan bernegara. ${ }^{10}$

Kaitannya dengan pembahasan mengenai konstitusi di atas, Negara Indonesia sendiri menggunakan konsep berdemokrasi dalam ketentuan konstitusi yang ada. Maka dengan demikian demokrasi adalah bagian dari konstitusi. Demokrasi sendiri dapat dipahami sebagai sebuah dasar bernegara, di mana dalam berdemokrasi kekuatan rakyat memiliki pengaruh yang sangat besar yang mana mengenai kehidupannya atau dalam menilai kebijakan negara. Sebab kebijakan-kebijakan negara tersebut harus mampu mengakomodir seluruh kepentingan rakyat, karena hakikatnya dalam berdemokrasi yang mana kekuasaan tertinggi berada pada rakyat, dengan demikian maka bukan sesuatu yang tidak mungkin pembatasan atas kekuasaan dalam kebijakan negara berangkat

9 Johanes Suhardja, "Supremasi Konstitusi Adalah Tujuan Negara", Jurnal Dinamika Hukum, Vol. 10, No. 3. Pada 3 September 2010, 266.

${ }^{10}$ Fais Yonas Bo'a, UUD 1945, MPR dan Keniscayaan Amandemen: Terkait Kewenangan Konstitutif MPR dan Kebutuhan Amandemen Kelima UUD 1945, (Yogyakarta: Pustaka Pelajar, 2018), 49. 
Politica, Vol. 7, No. 2, Juli-Desember 2020

dari kepentingan rakyat, begitulah sejatinya nilai konstitusi yang baik dalam sebuah negara yang menganut konsep demokrasi.

\section{Pembatasan Kekuasaan Menurut Konsep Konstitusionalisme}

Sudah disebutkan sebelumnya bahwa tujuan bernegara adalah tidak lain untuk mencapai sebuah cita yang ingin diraih, pendapat tersebut dikemukakan oleh (Mansyur Semma, 2008;19). Locke juga berpendapat yang mengatakan bahwa negara diciptakan oleh masyarakat maka oleh sebab itu sudah pasti tujuan negara adalah untuk melindungi hak-hak yang dimiliki oleh masyarakat. ${ }^{11}$ Kaitannya dengan tujuan sebuah negara maka sudah menjadi suatu kewajiban membahas mengenai kekuasaan yang terdapat dalam negara itu sendiri, baik organ-organ atau lembaga yang ada didalam negara tersebut.

Beberapa tokoh memiliki pandangan atau pendapat berbeda dalam mendefinisikan tentang sebuah kekuasaan dalam suatu negara. Sebut saja pendapat yang dikemukakan oleh Foucault yang menurutnya kekuasan itu berada dimana-mana bukan merupakan milik dari pemimpin organisasi tertentu. ${ }^{12}$ Sedangkan pendapat lain yang dikemukakan oleh Tan Malaka yang menyebutkan bahwa kekuasaan dalam suatu organisasi atau negara bersifat absolut. Pendapat Tan Malaka yang mengartikan sebuah kekuasaan semacam itu tidak bisa seketika kita menganggapnya keliru atau tidak baik jika kita kaitkan dengan konsep kekuasaan dalam negara demokrasi misalnya di Indonesia. Tan Malaka mengatakan demikian yang di mana ketika negara memiliki kekuasaan penuh dalam mengontrol sampai lapisan bawah, maka kebijakan-kebijakan negara yang mengarah pada pembangunan dan pemberdayaan masyarakat dapat dirasakan sampai ke lapisan masyarakat paling bawah.

Dengan demikian pendapat Tan Malaka tersebut tentang kekuasaan sepintas dapat kita nilai sangat baik. Namun bagaimana kalau kekuasaan negara yang bersifat absolut menurut Tan Malaka tersebut

\footnotetext{
${ }^{11}$ Encik Muhammad Fauzan, Hukum Tata Negara Indonesia, (Malang: Setara Press. 2017), 69.

${ }^{12}$ Muhammad Junaidi, Ilmu Negara: Sebuah Konstruksi Ideal Negara Hukum, (Malang: Setara Press. 2016), 62.
} 
Politica, Vol. 7, No. 2, Juli-Desember 2020

digunakan untuk membuat kebijakan yang tidak mendukung kepentingan rakyat, maka pendapat Tan Malaka yang mengartikan kekuasaan semacam itu bisa saja mengarah kepada sesuatu yang tidak baik bahkan negara yang menganut konsep kepemimpinan atau kekuasaan absolut tersebut malah akan mengakibatkan kehancuran jika diterapkan dalam suatu organisasi atau negara. Dengan demikian dapat kita simpulkan dari yang sudah dijelaskan panjang lebar sebelumnya terhadap pendapat yang dikemukakan oleh Foucault dan Tan Malaka tersebut di atas bisa mengarah pada hal-hal yang baik, namun sebaliknya akan terjadi kekeliruan jika kita mempraktekkan kekuasaan tersebut keluar dari nilai-nilai kepentingan rakyat. Dengan kata lain hal mengenai kekuasaan tersebut memerelukan konsep konstitusionalisme atau pembatasan-pembatasan untuk meminimalisir kemungkinan buruk yang akan terjadi.

Masih berkaitan dengan kekuasaan yang di mana terdapat pula pendapat dari Shang Yang, menurutnya tujuan utama membuat negara adalah untuk membentuk kekuasaan. ${ }^{13}$ Shang Yang mengatakan bahwa kalau kita ingin membuat negara yang kuat dan memiliki kekuasaan penuh maka rakyatnya harus dibuat menjadi lemah, sebaliknya jika kita hendak membuat rakyat menjadi kuat maka harus menjadikan negara itu lemah. "Aweak people means a strong state and a strong means a weak people therefore a country, wich has the right way, if conserned with weakening the people'.'Dari pendapat Shang Yang ini seakan memberikan jawaban kepada rakyat dalam menentukan sebuah sikap jika ingin mengembalikan kekuasaan tersebut sepenuhnya atas kepentingan rakyat.

Dari beberapa pendapat para tokoh di atas dalam mendefinisikan sebuah kekuasaan pada suatu negara dapat kita simpulkan bahwa pada dasarnya mengenai pembatasan terhadap suatu kekuasaan memang diperlukannya pembatasan-pembatasan, baik bagi kekuasaan organorgan, kelembagaan dan bentuk kekuasaan lainnya dalam sebuah negara demokrasi. Itu semua diperlukan untuk menjadi kontrol (checks and balances) baik terhadap suatu kebijakan yang ada didalam negara

${ }^{13}$ Ibid, hlm, 62-63. 
Politica, Vol. 7, No. 2, Juli-Desember 2020

tersebut. Indonesia merupakan negara hukum yang menganut sistem demokrasi, yang mana sebagai negara penganut sistem berdemokrasi sudah barang tentu bangsa Indonesia adalah negara konstitusi (constitutional state). Sebagaimana dipaparkan sebelumnya di atas mengenai konstitusi yang kokoh adalah sebuah negara yang mampu mengatur dan dapat memisahkan atau memberikan batas-batas kewenangan dan kekuasaan lembaga eksekutif, legislatif, dan yudikatif secara imbang dan saling mengawasi (checks and balances), serta memberikan hak-hak kepada rakyatnya.

Sebagaimana telah disebutkan di atas bahwa Indonesia merupakan negara hukum yang menganut konsep negara demokrasi, yang di mana dalam konstitusinya Indonesia membagi menjadi tiga cabang atau bagian pemerintahan yang memiliki kekuasaan, yakni kekuasaan eksekutif, legislatif, dan yudikatif. Di mana ketiga cabang pemerintahan yang memiliki kekuasaan tersebut atas dasar hukum dan nilai-nilai konstitusi yang ada di Negara Indonesia, tentunya juga memiliki batas-batas kekuasaan, baik dalam menentukan suatu kebijakan untuk rakyat dan lain sebagainya. Dibawah ini akan dipaparkan mengenai batas-batas kekuasaan yang dimiliki ketiga cabang pemerintahan tersebut menurut paham konstitusionalisme dalam sebuah negara hukum penganut konsep demokrasi seperti halnya Negara Indonesia.

\section{1) Kekuasaan Negara}

Sebelum membahas ketiga cabang pemerintahan yang memiliki kekuasaan tersebut, yakni eksekutif, legislatif, dan yudikatif sedikit kita bahas terlebih dahulu tentang apa yang dimaksud dengan kekuasaan yang dimiliki oleh suatu negara itu sendiri. Jadi negara adalah sebuah organisasi kekuasaan yang dijalankan menurut sistem pemerintahannya berdasarkan konstitusinya. Di mana konstitusi tersebut sangat menentukan jalannya sebuah organisasi kekuasan yang di mana apakah nantinya berjalan atas dasar kedaulatan tuhan, kedaulatan raja, 
Politica, Vol. 7, No. 2, Juli-Desember 2020

kedaulatan rakyat atau kedaulatan hukum. ${ }^{14}$ Indonesia sebagai negara hukum yang di mana kekuasaan negara telah disebutkan atau diatur dalam Undang-Undang Dasar Negara Republik Indonesia (UUD NRI) 1945. Disebutkan disitu bahwa sumber kekuasaan Negara Indonesia adalah berasal dari kedaulatan rakyat. Maka dengan demikian segala kekuasaan Negara Indonesia tersebut berdasarkan kedaulatan rakyat yang dijalankan sesuai perundang-undangan.

Jika kita menengok sejarah, berkaitan dengan pemisahan kekuasaan maka dulu sebelum adanya perubahan atau amandemen Undang-Undang Dasar (UUD) 1945 yang di mana berkaitan dengan kekuasaan bahwa kedaulatan rakyat berada pada Majelis Permusyawaratan Rakyat (MPR). Kedudukannya sebagai lembaga tertinggi membuktikan bahwa MPR memiliki wewenang atau kekuasaan memilih Presiden dan Wakil Presiden. Setelah terjadi perubahan atas UUD NRI Tahun 1945 kemudian memisahkan kekuasaan negara yang terdiri dari kekuasaan eksekutif, legislatif, dan yudikatif. Adapun tujuannya adalah untuk mewujudkan suatu pemerintahan yang baik dan kekuasaan negara tidak pada satu orang seperti halnya sebelum perubahan UUD NRI yang di mana MPR memiliki kuasa atas pemilihan Presiden dan Wakil Presiden.

John Locke mengatakan bahwa kekuasaan untuk membentuk undang-undang dan melaksanakan undang-undang tidak boleh dipegang oleh orang yang sama. ${ }^{15}$ Di mana menurutnya jika kedua jenis kekuasaan tersebut dipegang oleh satu orang, satu organorgan, atau satu lembaga negara maka orang atau lembaga tersebut tidak akan bisa berlaku adil. Sebagai gambaran, Dewan Perwakilan Rakyat (DPR) memiliki kekuasaan untuk membuat undang-undang untuk dilaksanakan oleh lembaga lain termasuk DPR itu sendiri, dan undang-undang yang telah dibuat DPR tersebut digunakan oleh kekuasaan eksekutif, dan juga yudikatif. Maka dengan demikian disitu terdapat saling mengontrol (checks and balances)

${ }^{14}$ Encik Muhammad Fauzan, Hukum Tata Negara Indonesia, (Malang: Setara Press. 2017), 68.

${ }^{15}$ Ibid, hlm, 69-70. 
Politica, Vol. 7, No. 2, Juli-Desember 2020

antara ketiga cabang pemerintah pemilik kekuasaan tersebut. Ini berarti pendapat John Locke di atas sudah diterapkan oleh bangsa Indonesia, di mana tidak ada pembentukan dan pelaksanaan undang-undang dilakukan oleh satu orang atau lembaga.

\section{2) Kekuasaan Organ-organ Negara}

Sebagamana telah disinggung sebelumnya di atas mengenai batas kekuasaan sebuah negara maupun organ-organ atau lembaga yang ada didalamnya. Indonesia sebagai negara hukum dengan sistem demokrasi konstitusional dan Undang-Undang Dasar menjadi sebuah pijakan hukumnya mempunyai fungsi untuk membatasi kekuasaan ketiga cabang pemerintahan pemilik kekuasaan seperti eksekutif, legislatif, dan yudikatif. Sehingga dengan demikian pelaksanaan atau penyelenggaraan sebuah kekuasaan yang dimiliki oleh pemerintah tidak dilaksanakan secara wewenang-wenang. ${ }^{16}$ Maka dengan demikian hak-hak atau kepentingan rakyat dapat dirasakan. Konsep seperti inilah yang dinamakan konstitusionalisme menurut (Dahlan Thaib, 2008; 19).Hal ini juga senada dengan pendapat Mahfud MD yang menyebutkan bahwa konstitusionalisme murupakan sebuah gagasan politik tentang bagaimana membatasi kekuasaan pemerintah melalui pembuatan konstitusi, ${ }^{17}$ baik tertulis maupun tidak tertulis. Pendapat Mahfud MD ini dapat kita lihat pada Pasal 18B Ayat (2) Undang-Undang Dasar (UUD) 1945 bahwa secara konstitusi negara mengakui keberadaan masyarakat adat, baik menghormati hak-hak atau hukum adat yang berlaku. Ini berarti negara telah membatasi diri dalam hal kepentingan masyarakat adat, yang di mana meski hukum adat yang berlaku tidak secara eksplisit bahkan tidak tertulis sama sekali dalam peraturan undangundang namun keberadaan hukum adat tetap diakui oleh hukum yang berlaku di Negara Indonesia.

\footnotetext{
${ }^{16}$ Muhammad Junaidi, Ilmu Negara: Sebuah Konstruksi Ideal Negara Hukum, (Malang: Setara Press. 2016), 98.

${ }^{17}$ Ibid, hlm, 99-100.
} 
Politica, Vol. 7, No. 2, Juli-Desember 2020

Kekuasaan eksekutif menurut Wynes adalah melaksanakan undang-undang dan menyelenggarakan urusan pemerintahan agar terciptanya ketertiban, keamanan dan sebagainya. ${ }^{18}$ Sedangkan menurut Bagir manan tugas atau wewenang pemerintah dapat dibagi kedalam beberapa golongan, yakni tugas dan wewenang administrasi penyelenggaraan tata usaha negara, administrasi bidang keamanan, administasi bidang pelayanan umum, dan administrasi bidang penyelenggaraan kesejahteraan umum. Kekuasaan eksekutif ini juga disebutkan dalam UUD NRI Tahun 1945 bahwa kekuasaan pemerintah mecangkup bidang administrasi, bidang kehakiman, bidang militer dan bidang diplomatik.

Kekuasaan eksekutif ini dipegang oleh presiden dan wakil presiden. Dalam hal kekuasaannya yang paling menonjol dari beberapa bidang kekuasaan pemerintah atau presiden yang sudah dipaparkan di atas adalah bidang penyelenggaraan perundangundangan atau administrasi tata usaha negara dan bidang kewenangan kehakiman. Melalui kedua bidang kekuasaan presiden inilah yang secara langsung berhadapan atau bersentuhan dengan kepentingan rakyat. Sebagai gambaran bahwa seorang presiden memiliki hak dalam mengajukan rancangan undang-undang. Setiap rancangan undang-undang tersebut harus mendapat persetujuan DPR. Selain itu presiden juga berhak menetapkan peraturan pemerintah untuk menjalankan undang-undang dan membentuk peraturan presiden. Namun meski demikian kekuasaan yang dimiliki presiden dibatasi oleh kekuasaan legislatif atau dalam hal ini Dewan Perwakilan Rakyat (DPR), seperti yang disebutkan di atas bahwa kekuasaan presiden dalam menetapkan peraturan pemerintah, peraturan presiden dan lain sebagainya harus mendapatkan persetujuan DPR, maka dalam hal itu apapun kebijakan yang akan dikeluarkan oleh presiden sebagai pemegang kekuasaan eksekutif terdapat batasan kekuasaan.

${ }^{18}$ Encik Muhammad Fauzan, Hukum Tata Negara Indonesia, (Malang: Setara Press. 2017), 80. 
Politica, Vol. 7, No. 2, Juli-Desember 2020

Selain itu dalam bidang kewenangan kehakiman, yang di mana seorang presiden memiliki kekuasaan dapat mengeluarkan grasi atau hak seorang presiden memberikan pengurangan hukuman, kemudian dapat megeluarkan keputusan rehabilitasi, amnesti, dan abolisi. Di mana dalam beberapa kekuasaan kewenangan dalam bidang kehakiman ini seorang presiden memiliki hak sepenuhnya tanpa campur tangan kekuasaan yudikatif. Kekuasaan presiden dalam bidang kehakiman ini disebut sebagai hak prerogatif, menurut Thomas Jefferson hak prerogatif tersebut merupakan perintah sebuah konstitusi negara yang diberikan kepada presiden. Di mana di Indonesia sendiri sebelum amandemen UUD 1945 disebutkan bahwa hak prerogatif presiden tersebut adalah hak absolut seorang presiden tanpa campur tangan siapapun.

Sebagai gambaran bahwa ketika presiden mengeluarkan keputusan memberikan grasi, rehabilitasi, amnesti, dan abolisi yang di mana keputusannya itu merupakan hak prerogatif seorang presiden. Contoh dalam undang-undang tentang pemberian grasi menyebutkan bahwa pemberian grasi tersebut bukan merupakan campur tangan bidang yudikatif atau kewenangan kehakiman melainkan hak prerogatif presiden dalam memberikan pengampunan. Akan tetapi meskipun dalam undang-undang disebutkan bahwa pemberian grasi oleh presiden tersebut tanpa campur tangan bidang yudikatif namun tetap saja harus melihat pertimbangan Mahkamah Agung.

Maka kesimpulannya adalah kekuasaan eksekutif atau kekuasaan presiden terdapat pembatasan kekuasaan, seperti yang sebelumnya disebutkan di atas ketika seorang presiden akan mengeluarkan peraturan pemerintah atau peraturan presiden dan lain sebagainya harus mendapat persetujuan Dewan Perwakilan Rakyat (DPR), begitu juga ketika berkaitan dengan kewenangan presiden dalam bidang kekuasaan kehakiman, di mana seorang presiden dalam menggunakan hak prerogatifnya tentu harus melihat pertimbangan DPR dan Mahkamah Agung. Itu berarti jika kita melihat konsep konstitusionalisme dalam hal kekuasaan eksekutif maka sudah terpenuhi terhadap konteks adanya saling 
Politica, Vol. 7, No. 2, Juli-Desember 2020

kontrol atau checks and balances yang di mana kepentingan rakyat terwakili melaui DPR ketika pemerintah ingin mengeluarkan suatu kebijakan yang berkaitan dengan kepentingan rakyat.

Organ kekuasaan pemerintah selanjutnya adalah berada pada kekuasaan legislatif atau kekuasaan pembuat undang-undang. Yang masuk dalam kekuasaan legislatif ini adalah Dewan Perwakilan Rakyat (DPR), menurut Jimly Asshiddiqie DPR memiliki tiga fungsi yakni fungsi legislasi, anggaran dan pengawasan. ${ }^{19}$ Menurutnya secara lebih luas fungsi lembaga perwakilan rakyat tersebut adalah fungsi pengaturan, fungsi pengawasan dan fungsi perwakilan. Melihat fungsi secara umunya DPR merupakan perwakilan rakyat, ${ }^{20}$ yang mana jika kita kaitkan dengan konsep konstitusionalisme maka sudah seharusnya lembaga perwakilan rakyat tersebut mengutamakan kepentingan rakyat sesuai dengan dasar negara hukum konstitusi bahwa kedaulatan berada pada tangan rakyat.

Dengan demikian jika melihat dari fungsi pengaturan dan perwakilan dapat kita interpretasikan bahwa dalam tugas membuat undang-undang maka sudah seharusnya Dewan Perwakilan Rakyat (DPR) tersebut harus melihat kepentingan rakyat dalam setiap peraturan perundang-undangan yang mereka buat. Begitulah amanat konstitusi yang seharusnya. Namun faktanya tidak sedikit undang-undang yang disahkan oleh DPR berujung penolakan dari kalangan masyarakat umum, para aktivis, mahasiswa dan lain sebagainya. Baru-baru ini pada 5 Oktober 2020 DPR mengesahkan peraturan perundang-undangan Omnibus Law yang di mana didalamnya yang paling banyak dipermasalahkan oleh masyarakat adalah tentang peraturan cipta lapangan kerja yang di mana dinilai tidak mendukung kepentingan rakyat. ${ }^{21}$

19 Jimly Asshiddiqie, Pokok-Pokok Hukum Tata Negara Indonesia, Pasca Reformasi, Bhuana Ilmu Populer, (Jakarta: 2007), 154.

${ }^{20}$ Ibid, hlm, 160.

${ }^{21}$ Fajar Pebrianto, 'Gelombang Penolakan Omnibus Law', dalam https://bisnis.tempo.com, diakses tanggal 11 Oktober 2020, Pukul 10.11. 
Bukan hanya itu, bahwa tidak sedikit pemberintaan atau kejadian pada masa-masa lampau tentang penolakan kebijakan yang dibuat oleh lembaga legislatif tersebut karena lagi-lagi dalam peraturan undang-undang yang dibuat dianggap tidak memngutamakan kepentingan rakyat, itu berarti nilai kedaulatan berada di tangan rakyat sudah diabaikan padahal itu merupakan amanat konstitusi. Namun dibalik itu semua, rakyat masih memiliki harapan berdasarkan konsep konstitusional yang ada, sebut saja peraturan dalam Undang-Undang Nomor 12 Tahun 2011 tentang Pembentukan Peraturan Perundang-Undangan bahwa DPR bersama presiden diberikan waktu selama 30 hari untuk menyetujui undang-undang yang sebelumnya disahkan di lembaga legislatif.

Ini berarti secara konstitusi presiden memiliki kekuasaan dapat menolak undang-undang yang dibuat tersebut dengan tidak meneken lalu kemudian mengeluarkan Peraturan Pemerintah Pengganti Undang-Undang (Perpu). Namun cara ini menurut para pakar Hukum Tata Negara memang tidaklah semudah yang dibayangkan jika presiden menolak undang-undang yang sebelumnya dibuat oleh lembaga legislatif tersebut. Seperti yang sudah disebutkan sebelumnya bahwa peraturan pemerintah, peraturan presiden dan kekuasaan lainnya yang dimilki presiden harus melalui persetujuan DPR. Itu berarti sekalipun Peraturan Pemerintah Pengganti Undang-Undang (Perpu) yang dikeluarkan oleh presiden untuk menolak undang-undang yang dibuat DPR kemungkinannya sangat kecil untuk disetujui, atau meskipun akan disetuji perubahan dalam poin-poin peraturan tersebut tidak akan terlalu besar dari poin undang-undang sebelumnya.

Lalu menurut konstitusi lainnya bahwa jika cara tersebut di atas tidak berhasil, maka langkah selanjutnya bagi masyarakat untuk memperjuangkan haknya biasa memalui uji matari ke Mahkamah Konstitusi (MK) terhadap undang-undang yang tadinya dibuat oleh DPR yang dinilai tidak mendukung rakyat. Maka dalam hal ini dapat kita simpulkan bahwa kekuasaan yang dimiliki oleh legilatif juga sama halnya dengan kekuasaan yang dimiliki eksekutif, sama-sama dibatasi oleh konstitusi yang ada di negara 
Politica, Vol. 7, No. 2, Juli-Desember 2020

tersebut. Seperti yang dipaparkan sebelumnya bahwa peraturan undang-undang yang dibuat oleh DPR tersebut bisa saja mendapat penolakan dari presiden sebagai pemegang kekuasaan eksekutif, atau bisa saja akan tertolak sepenuhnya ketika uji materi terhadap undang-undang tersebut di Mahkamah Konstitusi (MK) sebagai pemegang kekuasaan yudikatif. Maka dengan demikian secara konstitusi ataupun jika merujuk pada konsep atau paham konstitusionalisme seperti yang disebut sebelumnya maka checks and balances atau kontrol terhadap kebijakan legislatif ini juga tetap ada, dengan kata lain terdapat pembatasan kekuasaan.

Lalu kemudian selajutnya adalah cabang kekuasaan pemerintah bidang yudikatif. Kekuasaan yudikatif ini dipegang oleh Mahkamah Agung (MA), Mahkamah Konstitusi (MK), dan Komisi Yudisial (KY), perlu diketahui KY memang tidak melaksanakan tugas peradilan namun tetap berperan dalam bidang kekuasaan kehakiman (Pasal 24B UUD NRI 1945). Di mana secara umum kekuasaan yudikatif ini berfungsi sebagai pemberi hukuman atau sanksi terhadap adanya suatu pelanggaran dari ketentuan undang-undang. Di Indonesia yudikatif ini dikenal sebagai penyelenggara kekuasaan kehakiman, yang di mana secara umum kekuasaan kehakiman ini dapat kita pahami sebagai suatu kekuasaan yang merdeka untuk menyelenggarakan peradilan dengan tujuan terselenggaranya penegakan hukum demi tercapainya keadilan. K. Wantjik Saleh mengatakan bahwa kekuasaan kehakiman itu terpisah dari campur tangan kekuasaan pemerintah atau eksekutif dan kekuasaan perundang-undangan atau legislatif dan juga merdeka dari pengaruh kedua kekuasaan tersebut. $^{22}$

Rimdan mengatakan bahwa kekuasaan kehakiman yang merdeka tersebut melekat pada hakim maupun lembaga kehakiman yang bersumber dari konstitusi dalam mengadili dan memberikan suatu putusan. $^{23}$ Bagir manan juga megatakan bahwa yang

${ }^{22}$ Encik Muhammad Fauzan, Hukum Tata Negara Indonesia, (Malang: Setara Press. 2017), 102.

${ }^{23}$ Ibid, hlm, 102.103. 
dimaksud kekuasaan kehakiman yang merdeka tersebut adalah tidak ada campur tangan baik pihak eksekutif dan legislatif dan pihak manapun ketika kekuasaan kehakiman dalam memutus suatu perkara. Jadi dapat kita pahami bahwa kekuasaan yang merdeka yang sebelumnya didefinisikan untuk memaknai kekuasaan kehakiman tersebut bukan merdeka atau bebas sebebasnya, namun dalam ranah ketentuan mengadili, memberi putusan, dan lain sebagainya yang tentunya tidak keluar dari konteks atau amanat konstitusi yang ada. Ini berarti jika kita menelaah pendapat Rimdan di atas maka kekuasaan kehakiman atau lembaga kehakiman tersebut harus berdasarkan peraturan konstitusi yang ada, dengan kata lain ada pembatasan kekuasaan yang merdeka tersebut oleh konstitusi dengan tujuan agar kekuasaan kehakiman tersebut tidak sewenang-wenang dalam melaksanakan kekuasaan yang merdeka itu.

Dapat kita simpulkan bahwa kekuasaan yudikatif atau kekuasaan kehakiman ini sedikit berbeda dengan kekuasaan eksekutif dan kekuasaan legislatif yang secara langsung memiliki hubungan timbal balik terkait kekuasaannya. Seperti kekuasaan eksekutif misalnya dalam mengeluarkan kebijakan maka harus mendapat persetujuan lembaga legislatif, begitu sebaliknya di mana ketika legislatif mengeluarkan peraturan undang-undang maka kekuasaan eksekutif dapat mengontrol dengan sikap mengeluarkan Peraturan Pemerintah Pengganti Undang-Undang (Perpu) sebagai penolakan jika peraturan tersebut dinilai tidak mementingkan rakyat. Sedangkan kekuasaan yudikatif atau kekuasaan kehakiman dalam melaksanakan peran kekuasaan yang sebelumnya dimaknai sebagai suatu kekuasaan yang merdeka langsung di kontrol oleh konstitusi yang ada, meski memang pada dasarnya ketentuan-ketentuan dalam konstitusi tersebut berasal dari negara atau dalam hal ini ketentuan pengaturan dalam konstitusi tersebut pada dasarnya lahir dari eksekutif dan legislatif yang berupa undang-undang sebagai legalitasnya.

Jadi dapat kita pahami bahwa letak perbedaan kekuasaan yudikatif ini adalah tidak secara langsung dapat di kontrol oleh 
Politica, Vol. 7, No. 2, Juli-Desember 2020

kekuasaaan eksekutif dan legislatif, atau dengan kata lain, batasan kekuasaan yudkatif ini adalah berada pada ketentuan konstitusi atau batasan yang didapat langsung dari internal kekuasaan yudikatif itu sendiri, seperti halnya pengawasan dari KY dalam menjaga warwah hakim baik dari proses seleksi dan sebagainya. Meski memang pada dasarnya akan tetap melibatkan persetujuan legislatif atau eksekutif misalnya dalam menentukan hakim agung dan lainnya. Lantas timbul pertanyaan, dimana letak perbedaan atau ketidak terkaitan kekuasaan yudikatif tersebut dengan kekuasaan eksekutif dan legislatif. Maka untuk menjawabnya adalah dengan melihat pada kekuasaan yudikatif yang tereletak pada kekuasaannya yang bersifat merdeka dalam menentukan suatu putusan pada ranah peradilan tanpa campur tangan dan pengaruh pihak manapun termasuk eksekutif dan legislatif, yang di mana hanya produk hukum dari kekuasaan eksekutif atau kekuasaan legislatif yang sudah tertuang dalam undang-undang atau masuk sebagai ketentuan konstitusi yang dapat membatasi kekuasaan tersebut.

Selain itu sudah dijelaskan sebelumnya bahwa kekuasaan kehakiman ini yang dapat diawasi oleh pihak internal seperti Komisi Yudisial (KY) juga dapat melibatkan masyarakat, di mana keberadaan KY selama ini telah memfasilitasi masyarakat dalam membuat permohonan pengawasan terhadap perilaku hakim dalam sebuah persidangan. Maka dengan kata lain kekuasaan yudikatif ini juga memiliki batasan yang nyatanya lebih luas dari pembatasan kekuasaan eksekutif dan legislatif. Karena seperti yang sudah dipaparkan, pembatasan kekuasaan tersebut datangnya dari amanat kosntitusi dalam bentuk undang-undang, batasan kekuasaan yang langsung diawasi pihak internal, dan tentunya batasan yang secara tidak langsung juga datang dari rakyat. Maka dalam hal ini jika lagi-lagi kita kaitkan dengan konsep atau paham konstitusionalisme maka kekuasaan eksekutif, legislatif dan yudikatif tersebut mempunyai batasannya masing-masing. Dengan demikian dapat kita simpulkan bahwa sejauh ini asas kedaulatan masih berada pada tangan rakyat jika kita melihat secara regulasi 
Politica, Vol. 7, No. 2, Juli-Desember 2020

yang ada atau pengaturan yang tertuang dalam undang-undang dan lain sebagainya. Terlepas terlaksananya atau tidak maka hanya fakta dan peristiwa dilapangan yang dapat menjawab itu semua.

\section{E. Kesimpulan}

Paham konstitusioalisme mempunyai norma khusus yang salah satu fungsinya yaitu memberikan batasan kekuasaan dengan prinsip rasional dan negara yang menganut paham ini adalah negara hukum yang menggunakan konsep demokrasi.Yang di mana negara demokrasi membutuhkan sebuah konstitusi yang bersifat kokoh yaitu konstitusi yang paham terhadap konstitusinya, secara rinci mengatur batas-batas kewenangan dan kekuasaan lembaga eksekutif, legislatif dan yudikatif. Maka dengan demikian pembatasan kekuasaan didalam negara demokrasi secara konstitusi memang sangat diperlukan, baik didalam kekuasaan organ-organ kelembagaan dan bentuk kekuasaan lainnya dalam sebuah negara, itu semua diperlukan untuk menjadi kontrol (checks and balances) serta dapat menuju sebuah asas pemerintahan yang baik (good government) agar tidak terjadi tumpang tindih dan sewenang-wenang dalam melaksanakan kekuasaan tersebut.

\section{DAFTAR PUSTAKA}

Ali Syafa'at, Muchamad, Konstitusi dan Demokrasi, Malang: Universitas Brawijaya, 2014.

Asshiddiqie, Jimly, Pokok-Pokok Hukum Tata Negara Indonesia, Pasca Reformasi, Jakarta:Bhuana Ilmu Populer 2007.

Bo'a, Fais Yonas, UUD 1945, MPR dan Keniscayaan Amandemen: Terkait Kewenangan Konstitutif MPR dan Kebutuhan Amandemen Kelima UUD 1945, Yogyakarta: Pustaka Pelajar, 2018.

Fauzan, Encik Muhammad, Hukum Tata Negara Indonesia, Malang: Setara Press. 2017. 
Politica, Vol. 7, No. 2, Juli-Desember 2020

Hady, Nuruddin, Teori Konstitusi dan Negara Demokrasi, Edisi Revisi, Malang: Setara Press, 2016.

Junaidi, Muhammad, Ilmu Negara: Sebuah Konstruksi Ideal Negara Hukum, Malang: $\quad$ Setara Press. 2016.

K. Hirman, Benny, Mempertimbangkan Mahkamah Konstitusi, Cet 1, Jakarta: Gramedia, 2013.

Mahfud M. Moh..Demokrasi dan Konstitusi di Indonesia: Studi Tentang Interaksi Politik dan Kehidupan Ketatanegaraan, Jakarta: PT. Rineka Cipta, 2000.

Nasution, Adnan Buyung, Arus Pemikiran Konstitusionalisme seri Tata Negara, Jakarta: Kata Hasta Pustaka, 2007.

Pebrianto, Fajar,'Gelombang Penolakan Omnibus Law', dalam https://bisnis.tempo.com, diakses tanggal 11 Oktober 2020, Pukul 10.11.

Semma, Mansyur, Negara dan Korupsi: Pemikiran Mochtar Lubis Atas Negara, Manusia Indonesia, dan Perilaku Politik, Jakarta: Yayasan Obor Indonesia, 2008.

Suhardja, Johanes, "Supremasi Konstitusi Adalah Tujuan Negara", Jurnal Dinamika Hukum, Vol. 10, No. 3. Pada 3 September 2010.

Undang-Undang Nomor 12 Tahun 2011 tentang Pembentukan Peraturan Perundang-Undangan, Lembaran Negara Republik Indonesia Tahun 2011 Nomor 82, Tambahan Lembaran Negara Republik Indonesia 5234.

Undang-Undang Nomor 48 Tahun 2009 tentang Kekuasaan Kehakiman, Lembaran Negara Republik Indonesia Tahun 
Politica, Vol. 7, No. 2, Juli-Desember 2020 2009 Nomor 157, Tambahan Lembaran Negara Republik Indonesia 5076.

Utrecht, Pengantar Hukum Administrasi Negara Indonesia. Cet ke 4, Surabaya: Pustaka Tinta Mas. 1986.

Zoelfa, Hamdan, Konstitualisme Indonesia Untuk Pembatasan Kekuasaan diakses dari https://mkri.id/index.php?page=web.Berita\&id=7775, pada 9 Oktober 2020. 